\title{
Leadership Styles and Employees' Commitment among Government Hospitals in Dodoma City, Tanzania
}

\author{
George Stephen Matiko* \\ ORCID: 0000-0001-5957-4568 \\ Department of Leadership and Governance \\ Institute of Accountancy Arusha, Tanzania \\ Elias Elisha Mbuti \\ ORCID: 0000-0002-5840-3684 \\ Department of General Studies \\ Institute of Accountancy Arusha, Tanzania \\ *Corresponding Mail: georgestephen359@gmail.com
}

\begin{abstract}
Copyright resides with the author(s) in terms of the Creative Commons Attribution CC BY-NC 4.0. The users may copy, distribute, transmit and adapt the work, but must recognize the author(s) and the East African Journal of Education and Social Sciences
\end{abstract}

\begin{abstract}
This study aimed to explore leadership style and employee commitment among government hospitals in Dodoma City using the cross-sectional research design. The sample of 120 out of 889 employees was determined through simple random sampling procedure but only 102 returned the questionnaires. The following leadership styles were found to be existing: status quo, people oriented, democratic, task oriented and autocratic. Affective commitment, continuance commitment and normative commitment existed in the organizations under investigation. There is a significant positive correlation between commitment of employees and two styles of leadership: democratic leadership accounting for $24.1 \%$ and autocratic leadership, accounting for $5.6 \%$. There is no significant relationship between employees' commitment and the following leadership styles: task oriented, people oriented, status oriented and laissez faire. The study recommends that employees need to be appraised for their commitment to the organizations. This can be done through various types of motivation in order to maintain their commitment spirit. The leaders of the organizations should be encouraged to increase the use of democratic and autocratic leadership styles which have accounted for employees' commitment.
\end{abstract}

Keywords: Leadership styles, commitment, government, hospitals, organization.

How to cite: Matiko, G. S. and Mbuti, E. E. (2021). Leadership Styles and Employees' Commitment among Government Hospitals in Dodoma City, Tanzania. East African Journal of Education and Social Sciences 2(4), 105111. Doi: https://doi.org/10.46606/eajess2021v02i04.0133

\section{Introduction}

Employee commitment is the fundamental factor for effective organizational functioning. While this is true in all types of organizations, it is of more importance in health related organizations such as hospitals where employees deal with the life of people. According to Kiran, Hussain, Afzan and Gillan (2019), health organizations have a complex environment with different professionals. Nursing profession is one of them which has own important professional responsibilities that require strong leadership which motivates and ensures maximized commitment.

Studies have indicated that the style a leadership may have effect on the commitment of employees (Yasir, Imran, Irshad, Mohamad, \& Khan, 2016). 
Leadership that creates a room for employees to participate in decision making, for instance, provides opportunities for employees to voice their opinions and to share knowledge with both administrators and fellow workers. This improves the relationship between leaders and workers, leading to high level of participation and commitment (Ngussa \& Luicensi, 2017). Chirchir et al. (2014) as cited by Makewa, Ngussa, Arego and Kuboja (2015) established positive correlations between transformational leadership and normative commitment and between transactional leadership style and affective commitment of teachers; the authors recommended that transformational and transactional leadership attributes should be used to bring about maximized teachers' commitment.

On the contrary, poor leadership diminishes the rate of employees' commitment. Particularly, leadership styles that use the approach of top-down and commands may threaten the welfare of employees and result into negative reactions in the organizations (Gottfredson \& Reina, 2020). This may lead to endless conflicts instead of maximized commitment. These styles of leadership are associated with discouragement of employees and destruction of their commitment. It is also revealed that laissez faire leadership style may reduce the rate of employees' commitment as some workers need close monitoring for effective working (Abasilim et al., 2018).

\section{Organizational Commitment}

Organizational commitment is defined by Allen and Meyer (1994) in Silva and Mendis (2017) as the psychological tie between the organization and the employee, which increases the chance that the employee will remain with the organization and contribute above-average effort to the organization. This implies that once the employees are committed, they will give more input to the development of the organization and realization of the goals and objectives. Silva and Mendis (2017) further categorizes commitment into three types: continuance, normative and affective. While affective commitment has to do with employee's emotional attachment and identification with the organization, continuance commitment is measured by dedication of the employees and normative commitment has to do with employee's obligatory feelings to stay in their current situation. Similarly, Meyer and Allen (1991), Allen and Meyer (1997), Meyer and Herscovitch (2001) and Ugboro (2006) as cited by Al-Madi, Assal, Shrafat and Zeglat (2017) consider affective commitment as employee's identification with and involvement in the organization and continuance commitment as employee's awareness of costs associated with leaving the organization and normative commitment as employee's feelings of obligation to remain with the organization. All three types of commitment are important for organization to exist and reach its goals and objectives.

According to Aljarameez (2021), when coupled with high organizational demands, employees in health related institutions may develop low commitment, which in turn can contribute to disengagement and withdrawal from the organizations. According to Mubeen, Afza, Azhar and Gilani (2018), stress is a crucial factor that determines employees' job satisfaction and organizational commitment, which are key turnover predictors. This implies that less stressed nurses are likely to be satisfied with their work environment and to be committed in their work. This calls upon leadership in health organizations to avoid issues that may add stressful moments to employees in order to gain their full commitment in their jobs.

\section{Leadership Styles in Organizations}

There are different styles of leadership and each style has its unique features that may affect the daily operations in organizations positively. This section therefore highlights different types of leadership.

\section{Task versus People Oriented Leadership}

As the name suggests, task oriented leaders concentrate on task achievement than anything else. This type of leadership is less concerned with relationships in the working place. The study of Carmen, José, Luis and José (2009) attempted to compare the task oriented and relational oriented leadership styles and established that task-oriented leaders bring about higher group efficacy and positivism among members of the group while relationship-oriented leadership maintains greater cohesion between the group's members. Therefore, task leadership is likely to compromise group cohesion at the expense of task achievement. This is further seen in study findings by Harikaran and Jeevaraj (2015) that there is a negative correlation between task-oriented leadership style of principals and teacher's satisfaction, performance and absenteeism. According to Demirtas and Karaca (2020, p. 9), "a leader has either task-oriented or relationship-oriented behavior." 


\section{Status Quo Leadership}

The status quo leaders are those who protect their affairs at the expense of the organizational development. They are contrary to charismatic leaders whom Demirtas and Karaca (2020) describe as those that show confidence with high performances, taking risks against their status quo.

\section{Autocratic Versus Democratic Leadership}

The autocratic-democratic continuum describes two types of leaders: one who dictates and gives orders for daily operations in the organization and one who engages employees in deciding what should be done and how should it be done. Autocratic leadership is described by Kippenberger (2002) as a type of leadership that is characterized by the tight control of group activities with all decisions being made by the leader. It is contrary to the democratic leadership which focuses on group participation and majority rule. Kanu (2020) describes the autocratic leadership as one that holds all the powers of decision-making without consulting others. This kind of leadership results into lack of clear channel of communication between the leader and the group members as the power of decision-making entirely resides on the leader while the group members are facilitators of what has been decided by leaders.

\section{Laissez Faire Leadership}

Laissez faire leadership grants complete freedom to group or individual decisions without the leader's participation or direction. According to Kippenberger (2002), the laissez-faire leader has little concern for either the task or the people and only puts in the minimum effort required to keep the job running. He gives complete freedom for employees to act as they wish without any follow up. The leadership grants complete freedom to group or individual decision without the leader's participation or direction. Kanu (2020) has it that in Laissez Faire leadership type, the group members have total control on decision-making without the participation of the leader. This means that subordinates are free to do what they wish and the leader has no authority.

This study sought to investigate on leadership styles and employees' commitment. The study was guided by the following research questions:

1. What is the view of employees on the types of leadership styles that exist among government hospitals in Dodoma City?

2. What is the view of employees on their commitment among government hospitals in Dodoma City?

3. Is there significant relationship between leadership styles and the commitment of the employees among government hospitals in Dodoma City?

\section{Research Methodology}

\section{Design, Population and Sampling}

This study employed the cross-sectional design. The study population consisted of 899 employees in three hospitals in Dodoma City (Dodoma Regional Referral Hospital, Mirembe National Hospital and Makole Urban Health Centre). The random sample of 120 was determined. The researchers distributed the questionnaire to the sample but only 102 respondents $(85 \%)$ returned the questionnaire.

\section{Data Analyses Method}

The analysis involved frequencies and percentages to present the demographic characteristics of respondents, means scores and standard deviations to present the perception of respondents and Regression analysis to determine the interrelationships of variables under investigation.

Table 1: Reliability Test of the Questionnaire

\begin{tabular}{llcc}
\hline SN & \multicolumn{1}{c}{ VARIABLE } & ITEMS & CRONBACH'S ALPHA \\
\hline 1 & Task oriented Leadership & 3 & .686 \\
2 & Task Oriented Leadership & 3 & .786 \\
3 & Status Quo Oriented Leadership & 3 & .798 \\
4 & Autocratic & 5 & .846 \\
5 & Laissez Faire & 5 & .830 \\
6 & Democratic Leadership & 5 & .879 \\
7 & Affective Commitment & 6 & .909 \\
8 & Continuance Commitment & 5 & .936 \\
9 & Normative Commitment & 5 & .876 \\
\hline
\end{tabular}

\section{Validity and Reliability}

The validity of the questionnaire was ensured by subjecting it to two experienced leaders and two research experts who read the items and advised for further improvement prior to data collection (Creswell, 2014). The advice given was taken into 
consideration, and therefore the questionnaire was considered useful. Prior to data collection, reliability of the questionnaire was ensured through running the Cronbach's Alpha. Each variable was treated separately to ensure the internal consistency. The Cronbach's Alpha for each variable was above 0.6 which was set as minimally accepted Cronbach's Alpha.

\section{Results and Discussion}

This study employed both descriptive and inferential data analysis. The descriptive statistics involved frequencies and percentages to present demographic factors, mean scores and standard deviations to present the perception of respondents and regression analysis to establish the relationships that existed between the independent and the dependent variables.

\section{Demographic Characteristics of Respondents}

Respondents were characterized according to gender, duration of service, educational level and marital status. Male respondents were 47 (45.6\%) while females were 56 (54.4\%). Therefore, majority of respondents were females as compared to the males. As far as the duration of service is concerned, $53(51.5 \%)$ had served the organizations for five years or below, $13(12.6 \%)$ had served for six to ten years, $28(27.2 \%)$ had served for above ten years and $9(8.7 \%)$ did not indicate the duration of their service. Therefore, majority of the respondents had served the organization for five years or below.

Respondents were further categorized according to their education whereby 4 (3.9\%) had primary education, 26 (25.2\%) had secondary education, 62 (60.2) had tertiary education, 7 (6.8\%) had no formal education and 4 (4.9\%) did not indicate their education level. Finally, 42 (40.8) were single, 44 $(42.7 \%)$ were married, 10 (9.7\%) were divorced, 2
(1.9\%) were widows or widowers and 5 (4.9\%) did not indicate their marital status. Therefore, majority of respondents were married.

\section{Descriptive Analysis}

The first two research questions were descriptive in nature and therefore involved determination of mean scores and standard deviations of what respondents perceived about leadership styles and commitment of employees. The mean scores of respondents were interpreted according to the following criteria: 3.50 to $4.00=$ strong agreement, 2.50 to $3.49=$ agreement, 1.50 to $3.49=$ disagreement and 1.00 to $1.49=$ strong disagreement.

Research Question 1: What is the view of employees on the types of leadership styles that exist among government hospitals in Dodoma City?

This research question sought to establish the types of leadership that existed in the organizations under investigation.

As indicated in table 2, the mean scores for the first six items were between 2.50 and 3.49 which means that respondents agreed with such items. This means that Status Quo Oriented leadership, People Oriented Leadership, Democratic Leadership, Task Oriented Leadership and Autocratic Leadership Styles existed in the organizations under investigation. While each leadership style has weaknesses and strengths, it is worth noting that the existing leadership styles can supplement one another for effective performance to take place in the organizations under investigation.

The mean score for the last item was 2.3260. This means that respondents disagreed that Laissez-faire leadership style exists in the organizations under investigation.

Table 2: Types of Leaderships

\begin{tabular}{llccc}
\hline SN & Type of Leadership & Mean & Std. Deviation & Interpretation \\
\hline 1 & Status Oriented Leadership Style & 3.0243 & .60382 & Agree \\
2 & People Oriented Leadership Style & 3.0180 & .61647 & Agree \\
3 & Democratic Leadership Style & 2.9960 & .57975 & Agree \\
4 & Task Oriented Leadership Style & 2.9725 & .61707 & Agree \\
5 & Autocratic Leadership Style & 2.5257 & .67750 & Agree \\
6 & Laissez-Faire Leadership Style & 2.3260 & .70570 & Disagree \\
\hline
\end{tabular}

Laissez-faire is the type of leadership whereby the leader leaves the followers to do as they wish. Since the organizations under investigation are health related, dealing with the life of people, it is good to note that the leadership does not give freedom for the employees to do as they wish as this may threaten the life of customers.

Research Question 2: What is the view of employees on their commitment among government hospitals in Dodoma City? 
This research question sought to establish the commitment of employees in the organizations under investigation. The overall commitment of employees as seen in table 3 had the mean score of 2.7780 which is in the agreement category. The mean score of all the three types of commitment was between 2.50 and 3.49 meaning affective, continuance and normative commitments existed in the organizations under investigation. Therefore, it can be argued that employees in organizations under investigation are committed to their jobs.

Table 3: Commitment of Employees

\begin{tabular}{llccc}
\hline SN & \multicolumn{1}{c}{ Type of Commitment } & Mean & Std. Deviation & Interpretation \\
\hline 1 & Affective Commitment & 2.8910 & .65465 & Agree \\
2 & Continuance Commitment & 2.7220 & .78738 & Agree \\
3 & Normative Commitment & 2.8359 & .65020 & Agree \\
4 & Overall Commitment & 2.7780 & .65404 & Agree \\
\hline
\end{tabular}

\section{Hypothesis Testing}

Research Question 3: Is there significant relationship between leadership styles and the commitment of the employees among government hospitals in Dodoma City?

This research question called for testing of a null hypothesis which stated: there is no significant relationship between leadership styles and the commitment of the employees among government hospitals in Dodoma City. The hypothesis was tested through linear regression as described in table 4, 5, 6 and 7 which show the model summary, ANOVA, coefficients and excluded variables, respectively. While the model summary in table 4 shows that democratic leadership and autocratic leadership correlate with the commitment of the employees, table 5 and 6 indicate the $p$ value of below .05 which shows an existing significant positive correlation. While the multiple correlation coefficients is .557 , the coefficient of multiple determination is . 319 , which is interpreted as $31.9 \%$ of the variance in commitment of employees is accounted for by democratic and autocratic leadership. Therefore, the results of the regression using the stepwise method indicated that the model explained $31.9 \%$ and that the model was a significant predictor of commitment of employees. Democratic leadership accounted for $24.1 \%$ while autocratic leadership accounted for 5.6\%. According to Kippenberger (2002), autocratic leadership is a type of leadership that is characterized by the tight control of group activities. The nature of health related organizations under investigation leads us to commend this finding since health workers need to abide with strict rules for quality output. The identified influence of democratic leadership on the commitment would suggest that employees participate in setting rules and regulations and leaders are strict to make sure that what has been agreed together is being implemented.

Table 4: Model Summary

\begin{tabular}{|l|c|c|c|c|}
\hline Model & $\mathrm{R}$ & R Square & $\begin{array}{c}\text { Adjusted R } \\
\text { Square }\end{array}$ & $\begin{array}{c}\text { Std. Error of the } \\
\text { Estimate }\end{array}$ \\
\hline 1 & $.520^{\mathrm{a}}$ & .271 & .263 & .55686 \\
2 & $.577^{\mathrm{b}}$ & .333 & .319 & .53547 \\
\hline
\end{tabular}

a. Predictors: (Constant), Democratic Leadership

b. Predictors: (Constant), Democratic Leadership, Autocratic Leadership

Table 5: ANOVA $^{a}$

\begin{tabular}{|ll|c|c|c|c|c|}
\hline Model & & Sum of Squares & $\mathrm{df}$ & Mean Square & $\mathrm{F}$ & Sig. \\
\hline 1 & Regression & 11.056 & 1 & 11.056 & 35.653 & $.000^{\mathrm{b}}$ \\
& Residual & 29.769 & 96 & .310 & & \\
& Total & 40.825 & 97 & & & \\
\hline 2 & Regression & 13.586 & 2 & 6.793 & 23.692 & $.000^{c}$ \\
& Residual & 27.239 & 95 & .287 & & \\
& Total & 40.825 & 97 & & & \\
\hline
\end{tabular}

a. Dependent Variable: Commitment

b. Predictors: (Constant), Democratic Leadership

c. Predictors: (Constant), Democratic Leadership, Autocratic Leadership 
Table 6: Coefficients ${ }^{\mathrm{a}}$

\begin{tabular}{|c|c|c|c|c|c|c|}
\hline \multirow{2}{*}{\multicolumn{2}{|c|}{ Model }} & \multicolumn{2}{|c|}{ Unstandardized Coefficients } & \multirow{2}{*}{$\begin{array}{c}\begin{array}{c}\text { Standardized } \\
\text { Coefficients }\end{array} \\
\text { Beta }\end{array}$} & \multirow[b]{2}{*}{$\mathrm{T}$} & \multirow[b]{2}{*}{ Sig. } \\
\hline & & B & Std. Error & & & \\
\hline \multirow[t]{2}{*}{1} & (Constant) & 1.007 & .300 & & 3.362 & .001 \\
\hline & Democratic Leadership & .589 & .099 & .520 & 5.971 & .000 \\
\hline \multirow[t]{3}{*}{2} & (Constant) & .688 & .307 & & 2.238 & .028 \\
\hline & Democratic Leadership & .483 & .101 & .427 & 4.774 & .000 \\
\hline & Autocratic Leadership & .252 & .085 & .266 & 2.971 & .004 \\
\hline
\end{tabular}

a. Dependent Variable: Commitment

Table 7: Excluded Variables

\begin{tabular}{|c|c|c|c|c|c|c|}
\hline \multirow{2}{*}{\multicolumn{2}{|c|}{ Model }} & \multirow[b]{2}{*}{ Beta In } & \multirow[b]{2}{*}{$\mathbf{T}$} & \multirow[b]{2}{*}{ Sig. } & \multirow{2}{*}{$\begin{array}{c}\text { Partial } \\
\text { Correlation }\end{array}$} & $\begin{array}{c}\text { Collinearity } \\
\text { Statistics }\end{array}$ \\
\hline & & & & & & Tolerance \\
\hline \multirow[t]{5}{*}{1} & Task Leadership & $.101^{\mathrm{b}}$ & 1.060 & .292 & .108 & .841 \\
\hline & People Oriented Leadership & $.123^{b}$ & 1.286 & .201 & .131 & .820 \\
\hline & Status Oriented Leadership & $.191^{\mathrm{b}}$ & 1.893 & .061 & .191 & .724 \\
\hline & Autocratic Leadership & $.266^{\mathrm{b}}$ & 2.971 & .004 & .292 & .877 \\
\hline & Laissez Faire Leadership & $.179^{b}$ & 1.970 & .052 & .198 & .895 \\
\hline \multirow[t]{4}{*}{2} & Task Leadership & $.075^{\mathrm{c}}$ & .814 & .418 & .084 & .833 \\
\hline & People Oriented Leadership & $.119^{c}$ & 1.292 & .199 & .132 & .819 \\
\hline & Status Oriented Leadership & $.163^{c}$ & 1.660 & .100 & .169 & .716 \\
\hline & Laissez Faire Leadership & $.047^{c}$ & .439 & .662 & .045 & .619 \\
\hline
\end{tabular}

a. Dependent Variable: Commitment

b. Predictors in the Model: (Constant), Democratic Leadership

c. Predictors in the Model: (Constant), Democratic Leadership, Autocratic Leadership

Table 7 shows that the rest of leadership styles are excluded from the model and therefore, with the $p$ values of above .005, task leadership (.292), people oriented leadership (.201), status oriented leadership (.061) and laissez faire leadership (.052) have no correlation with commitment of the employees.

\section{Conclusions and Recommendations Conclusions}

The following leadership styles existed in the organization under investigation: Status Que, People Oriented, Democratic, Task Oriented and Autocratic. Laissez-faire leadership style did not exist in the organizations under investigation.

While affective, continuance and normative commitment existed in the organization under investigation; there is a significant relationship between commitment of employees and two types of leadership: Democratic leadership, accounting for 24.1\% and autocratic leadership, accounting for $5.6 \%$. There is no significant relationship between employees' commitment and the rest of leadership styles.

\section{Recommendations of the Study}

Based on the conclusions of the study, the researchers recommend that employees need to be appraised for their commitment to the organizations. This can be done through various types of motivation in order to maintain their commitment spirit. The leaders of the organizations under investigation should be encouraged to increase the use of democratic and autocratic leadership styles which have accounted for employees' commitment.

\section{References}

Abasilim, U. D., Gberevbie, D. E., \& Osibanjo, O. A. (2018, October 18-19). Does leadership styles relate with personnel commitment in private organisations in Nigeria? Paper presented at the 14th European Conference on Management, Leadership and Governance at HU University of Applied Sciences, Utrecht, The Netherlands.

Aljarameez, F. (2021). The Relationship of Structural Empowerment and Organizational Commitment among Staff Nurses in Saudi 
Arabia: A Comparative Correlational Crosssectional Study. Journal of Health, Medicine and Nursing 85(2021), 20-29.

Al-Madi, F. N., Assal, H., Shrafat, F., and Zeglat, D. (2017). The Impact of Employee Motivation on Organizational Commitment. European Journal of Business and Management 9(15), 134-145.

Carmen, T., José, C. M., Luis, C., and José, A. (2009). The Role of TaskOriented Versus Relationship-Oriented Leadership on Normative Contract and Group Performance. Social Behavior and Personality: an international journal 37(10), 1391-1404. From https://www.ingen taconn ect.com/content/sbp/sbp/2009/00000037/ 00000010/art00012

Churchill, G. A. \& Dawn I (2004): Marketing Research Methodological Foundations, $8^{\text {th }} \mathrm{Ed}$, Thompson Asia Pte. Ltd, Singapore.

Creswell, J W. (2014). Research design: qualitative, quantitative, and mixed methods approach (4th ed.). Thousand Oaks: SAGE Publications. ISBN 978-1-4522-2609-5.

Demirtas, O. and Karaca, M. (editors) (2020). A Handbook of Leadership Styles. Newcaslte, UK. Cambridge Scholars Publishers.

Gottfredson, R. K., \& Reina, C. S. (2020). Exploring why leaders do what they do: An integrative review of the situation-trait approach and situation-encodingschemas. The Leadership Quarterly, 31(1), 101373.

Harikaran, S., and Jeevaraj, L. (2015) Leadership Style of Principals and Teacher'S Behavior in Kilinochchi Zone Schools. European Journal of Business and Management 7(7), 49-57.

Kanu, A. F. (2020). Decentralized Health System Leadership: Are District Health Management Teams in Good Hands? Perspectives of 4 districts in Sierra Leone. Journal of Health, Medicine and Nursing 76(2020), 11-20.

Kiran, M., Hussain, M., Afzan, M., and Gillan, S. A. (2019). Impact of Professional Stress and Career Development on Organizational Commitment Among Nurses. Journal of Health, Medicine and Nursing 62(2019), 6673.

Kippenberger, T. (2002). Leadership Styles. United Kingdom. Capstone Publishing.

Makewa, L. N., Ngussa, B. M., Arego, S., and Kuboja, J. (2015). The correlates of leadership amongst selected secondary school stakeholders in Musoma municipality. International Journal of Educational Policy Research and Review 2(10), 129-140. DOI: http://dx.doi.org/10.15739/IJEPRR.022.

Mubeen, A., Afza, M., Azhar, M., and Gilani, S. A. (2018). Sources of Stress among Nurses at Tertiary Hospitals. Journal of Health, Medicine and Nursing 52(2018), 56-62.

Ngussa, B. M. and Gabriel, L. (2017). Participation in Decision Making and Teachers' Commitment: A Comparative Study between Public and Private Secondary Schools in Arusha Municipality, Tanzania. American Journal of Educational Research, 5(7),801- 807. doi: 10.12691/edu catio $n-5-7-17$.

Silva, D. A. C. S and Mendis, B. A. K. M. (2017). Relationship Between Transformational, Transaction and Laissez-faire Leadership Styles and Employee Commitment. European Journal of Business and Management 9(7), 13-21.

Yasir, M., Imran, R., Irshad, M. K., Mohamad, N. A., \& Khan, M. M. (2016). Leadership styles in relation to employees' trust and organizational change capacity: evidence from non-profit organisations. SAGE Open, 6(4). 